\title{
Foreign ownership and sustainability performance in Indonesia
}

\author{
Hesty Erviani Zulaecha1, Murtanto 2 \\ Faculty of Economics and Business, Trisakti University, \\ Indonesial,2 Email: hesty_erviani@yahoo.com ${ }^{1}$, \\ murayo2003@yahoo.com ${ }^{2}$
}

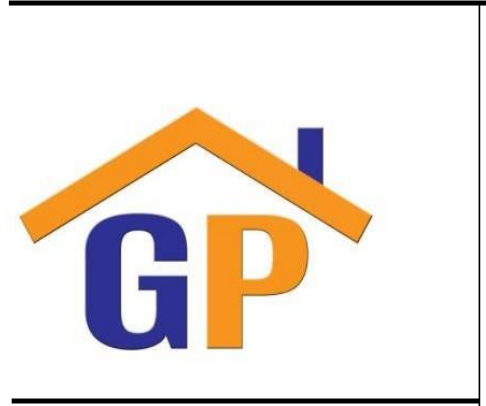

Article History

Received 16 April 2019

Revised 8 May 2019

Accepted 20 May 2019

\begin{abstract}
Purpose: This research is designed to find empirical evidence on the influence of Foreign Ownership as moderating to enterprise risk management, business strategy, and firm age on sustainability performance.
\end{abstract}

Research Methodology: This research was tested through random samples of 11 manufacturing companies period 20142017. Regression analysis was adopted to test the hypotheses

Results: The results indicate that enterprise risk management, business strategy, and foreign ownership have

significant influence to sustainability performance. But, the firm age doesn't have influence on sustainability performance.

Limitations: The use of secondary data and content analysis methods that cause limitations in conclusions and are subjective.

Contribution: This research shows that the harmonious relationship between strategic management related to enterprise risk management, business strategy, and the role of foreign ownership to achieve high sustainability performance.

Keywords: Sustainability performance, Business strategy, Foreign owner, Enterprise risk management, Firm age

How to Cite: Zulaecha, H. E., \& Murtanto. (2019). Foreign ownership and sustainability performance in Indonesia. International Journal of Financial, Accounting, and Management, 1(1), 1-15. https://doi.org/10.35912/ijfam.v1i1.39

\section{Introduction}

Foreign investors dominate the total share ownership in Indonesia Stock Exchange. Comparison of share ownership between foreign investors and local investors are 60\% and $40 \%$ (Chandra, 2016). Thus the return on company share ownership in Indonesia is enjoyed by foreign investors. Foreign investors tend to buy large shares of good companies for long-term ownership. Darwin Nasution, as Coordinating Minister for the Economy said thata number of industrial sectors were opened to foreign ownership to reach $100 \%$ in companies engaged in 54 fields of activity in the Standard Classification of Indonesian Business Fields (KBLI) which previously owned less than 100\% (Aditya \& Asmara, 2018).

Share ownership above $20 \%$ of all outstanding shares will have a significant influence, or in the majority of ownership of more than $50 \%$ indicates that the investor can exercise control, 
such as participation in determining policies, cooperating with other parties on behalf of the company and becoming one of the councils directors (Baker et al., 2009). Companies in carrying out their business must pay attention to stakeholders. The purpose of business is to create value and balance between economic, social and ecological sides (Melatic et al., 2015). With this balance, sustainability is achieved. Corporate practices that pay attention to these three dimensions should be supported by all parties, both internal and external parties.

In general, foreign ownership in multinational companies, especially in developing countries and globalization is a major cause of increasing companies in CSR involvement in Asian countries (Chappl e\& Moon, 2005; malik et al., 2017). But, the cases of environmental destruction in Indonesia involve foreign parties. Like the Montara case which caused a loss of Rp.27 trillion in the country, 18,882 square meters of coral reef companies were caused by the shipwreck of the Caledonian Sky vessel (Aderi \& Hasibuan, 2018).

Some studies include different results. Foreign ownership has a positive effect on CSR disclosure (Moustafa, 2012; Dalilawati, 2013;Darus et al., 2013). Hartikayanti (2016) and Winarti (2013) show the results that foreign share ownership has no effect. Kim et al. (2018) did not succeed in finding the impact of foreign ownership on CSR activities. This research aims to analyze influence of foreign ownership in the influence of enterprise risk management, business strategy and leverage on sustainability performance in manufacturing companies in Indonesia. Research that directly analyze the effect some factors are business strategy, enterprise risk management, firm age, and foreign ownership as moderating to sustainability performance, so the research will be found the evidence about it.

\section{Literature review and hypotheses development}

\section{The influence of Enterprise Risk Management on Sustainability Performance}

Corporate risk management is a process of determining strategy in all parts of the company. This process is carried out by the board of directors, management and other related parties to provide confidence that the company's goals are achieved in identifying potential events that can affect the company, and managing risk appetite (Casualty Actuarial Society Committee on ERM, 2003).

The purpose of the ERM system according to COSO (2004) is as follows:

a. Strategy: strategies set by the company try to achieve competitive advantage so that risk failures can be lower overall in the hope of increasing the performance and value of the company.

b. Operation: Organizational resources are used efficiently and effectively.

c. Reporting: reliable company reporting. If financial reporting cannot be trusted, it will increase risk.

d. Compliance: company compliance with applicable laws and regulations. Thus, the level of risk of corporate failure is lower so as to improve company performance

Based on the ERM objectives above, the company is expected to be able to manage risk by taking into account all interested parties both internal and external parties. Risk management also considers economic, social, environmental, legal, political and technological dimensions (www.wbcsd.com). The better the implementation of risk management, the greater the sustainability performance achieved by the company. With the above description, then the hypothesis in this study is as follow:

H1: Enterprise risk management has a positive association with sustainability performance

\section{The influence of Business Strategy on Sustainability performance}

Strategy is a tool needed to achieve success for a company (Lewis, 2008). Business strategies affect management systems, information systems, company operations, and reporting. Oltra and Flor (2010) said that business strategies determine the costs and resources used in producing products and are tailored to the company's goals. 
The type of business strategy based on Miles and Snow (1978) is defender, analyzer, prospector and reactor. In this study using a type of business strategy developed by Anwar and Hasnu (2016) on the basis of its distribution is based on Miles and Snow (1978).

Defender is a business strategy that focuses on maximum efficiency. In this strategy the company needs reliability in shipping with limited segments. Analyzer is a business strategy with the use of the core technology with the aim of operational efficiency without investing in large quantities of products and markets but flexible in the event of market changes. Prospector is a flexible strategy in the face of change, companies with this strategy prioritize the development of new products and become creators of change in an industry. Reactor is a business strategy that does not have specific competencies that are run by the company. This strategy is not feasible for long-term use (Miles and Snow, 1978; Anwar and Hasnu, 2016).

Jensen (2001) states that decisions made by companies must be adjusted for all stakeholders including customers, employees, and communities. The purpose of the company must be to benefit all stakeholders who pay attention to the economic, social and environmental dimensions, so that sustainability performance is achieved. With the above description, then the hypothesis in this study is as follow:

$\mathrm{H} 2$ : Business strategy has a positive association withsustainability performance

\section{The influence of Foreign Ownership on Sustainability performance}

Based on Law No. 25 of 2007 concerning Investment Article 1 paragraph 6, foreign capital ownership in a company within the territory of the Republic of Indonesia by foreign business entities, foreign governments and individual foreign nationals.

Foreign investment is considered in developing countries (Taiwo et al., 2017), as follows:

a. The entry of foreign capital into a country. With the entry of foreign capital can increase labor productivity

b. Efforts to improve the business climate in a country

c. The size of the market and natural resources

d. Mobilization of resources, reform and a conducive environment

e. The fastest and easiest way that can be done by developing countries to accelerate economic growth and infrastructure.

f. When a country with a large population, cheap labor is available.

Foreign investors may have more ability, more sophisticated technology, financial capital, technology, or human resources that are better than domestic investors (Hintošová \& Kubíková, 2016). Foreign ownership is more associated with the level of implementation of corporate governance. Corporate governance is a key factor in business success, because it is associated with improving sustainability performance and investor confidence (Saltaji \& Issam, 2013). Foreign ownership is believed to have greater attention related to environmental and social issues in decision making (Dam \& Scholtens, 2012; Malik et al., 2017). Sar (2014) found that there was a significant positive effect of corporate governance on sustainability. With the above description, then the hypothesis in this study is as follow:

H3: Foreign ownership has a positive association with sustainability performance

\section{The influence of Firm Age to Sustainability performance}

The age of the company is an important factor because the longer the life of the company, the more learning through trial and error in business, and building relationships (Marwa \& Aziakpono, 2015). The age of the company relates to experience, accumulation of knowledge in all aspects that are considered important in business such as better technology, good relationships with consumers, better resources and lower financing (Pervan et al., 2017). With the longer the company operates in an industry, the company will be better able to pay attention to all decisions and policies taken to achieve performance from economic, social and environmental aspects. Thus the age of the company can affect sustainability performance with the experience of knowledge and selection of actions to achieve the sustainability of the company. 
Research that states the influence of the firm on direct performance sustainability has not been found as long as the knowledge of the researcher. Trencansky et al. (2014) failed to show the influence of firm age on the level of CSR, so that it can be said to have no effect on sustainability. Osunsan et al. (2015) said that firm age has an effect on company performance.With the above description, then the hypothesis in this study is as follow:

H4:Firm age has a positive association with sustainability performance

\section{The influence of Foreign Ownership on Effect of Enterprise Risk Management toward Sustainability performance}

Companies that have foreign ownership have higher quality standards specially to meet consumers both local consumers and consumers outside of Indonesia. Consumers will prefer products that have better quality at affordable prices. this is evident that in fact $60 \%$ of local consumers prefer external products due to better quality at a more affordable price (Yulistara, 2018). Foreign ownership which generally has a better risk management system will influence the policies taken by the company. Foreign ownership to meet the needs of internal and external parties, has an information system that is more efficient and pays more attention to social and environmental dimensions. Thus it will strengthen the influence of enterprise risk management on sustainability performance.

H5: Foreign ownership positively moderates the relationship between enterprise risk management and sustainability performance

\section{The influence of Foreign Ownership on Business Strategy toward Sustainability Performance}

Foreign-based companies have greater demand from customers, suppliers and the general public (Hartikayanti \& Siregar, 2018). The business strategy carried out by companies in Indonesia in general is more emphasis on efficiency. The level of innovation in Indonesia is still low. This is proven by Indonesia being ranked 14th out of 15 countries in Southeast Asia and other Oceania countries in the Global Innovation Index (GGI) (Kurnia, 2018). With the presence of foreign ownership, it is expected that companies in Indonesia can better improve themselves by carrying out a strategy that prioritizes innovation, thus becoming a winner in trade competition in Indonesia and abroad. The innovation made by the company at this time is more concerned with the environment. Like Samsung, smartphone and television products in the development process technique are environmentally friendly (Dahwilani, 2017). With the innovation that pays more attention to the social and environmental dimensions besides the economy, it is expected that sustainability performance can be improved. With the above description, then the hypothesis in this study is as follows:

H6: Foreign ownership positively moderates the relationship between business strategy and sustainability performance.

\section{Research methodology \\ Research design}

The design of this research is associative (causal), because this study aims to analyze the influence of enterprise risk management, business strategy, leverage and foreign ownership to sustainability performance. The unit of analysis is the companies are listed on the Indonesia Stock Exchange. The horizon of this study was cross-sectional and longitudinal with a study period from 2014-2017.

\section{Data and Sample}

The population in this research is a manufacture companies that are listed in Indonesia Stock Exchange (BEI). Observation periods in this research are 2014-2017. The amount of sample this study is 11 companies which were selected by purposive sampling. 


\section{Research model}

The multiple regression analysis by using program SPSS 24 . Here is model of this research: Model 1

SUSTPERFit $=\alpha+\beta 1$ ERMit $+\beta 2$ STGRit $+\beta 3$ OWNit +

$\beta 4$ AGEit $+\varepsilon$ it Model 2

SUSTPERFit $=\alpha+\beta 1$ ERMit $+\beta 2$ STGRit $+\beta 3$ ERM_OWNit +

$\beta 4$ AGEit $+\varepsilon$ it Model 3

SUSTPERFit $=\alpha+\beta 1$ ERMit $+\beta 2$ STGRit $+\beta 3$ STRG_OWNit +

$\beta 4$ AGEit $+\varepsilon$ it Where:

SUSTPERFi,t $=$ Sustainability

Performance ERMi,t= Enterprise Risk

Management

STGRi, $\quad=$ Business Strategy

OWNi,t = Foreign Ownership

AGEi, $\quad=$ Firm Age

\section{Variables and Measurements}

\section{Variables and Measurements}

\begin{tabular}{|c|c|c|}
\hline Variable & Measurement & Source \\
\hline $\begin{array}{l}\text { Sustainability } \\
\text { Performance }\end{array}$ & $\begin{array}{l}\text { SUSTAIN }=\sum \text { ECOPERF }+\sum S O C P E R F+\sum E N V P E R F \\
\text { SUSTAIN = Sustainability Performance } \\
\text { ECOPERF = Economic Performance } \\
\text { SOCPERF = Social Performance } \\
\text { ENVPERF = Environmental Performance } \\
\text { a. Economic Performance } \\
\text { Economic Performance = Profitability }+ \text { Sales growth }+ \text { Market } \\
\text { Share + Company Image } \\
\text { b. Social Performance } \\
\text { Indicator Social Performance are: } \\
\text { 1. Attention to human resource development } \\
\text { 2. Work Health and Safety } \\
\text { 3. Relationship with the community and stakeholders } \\
\text { 4. Living quality of surrounding community } \\
\text { For measurement Social performance uses content analysis from } \\
\text { indicators in the table above using } 0 \text { - } 3 \text { assessment criteria. For brief } \\
\text { disclosure categories = 1, if disclosures are carried out in more detail } \\
\text { in one paragraph = 2, while disclosures are carried out in detail } \\
\text { accompanied by data quantitative = } 3 \text {, but if it is not disclosed = } 0 . \\
\text { The value interval from all environment performance indicators is } 0 \text { - } \\
\text { 12. } \\
\text { c. Environmental Performance } \\
\text { Indicator Environmental Performance are: } \\
\text { 1. CO2 emissions } \\
\text { 2. Wastewater } \\
\text { 3. Solid waste } \\
\text { 4. Toxic/harmful/ hazardous/flammable substances } \\
\text { 5. Greenhouse gas emissions } \\
\text { 6. Reduction of energy consumption }\end{array}$ & $\begin{array}{l}\text { Nguyen et al., } \\
2018\end{array}$ \\
\hline
\end{tabular}




\begin{tabular}{|c|c|c|}
\hline & $\begin{array}{l}\text { 7. Reduction of Water consumption } \\
\text { 8. PROPER Rank } \\
\text { To measure environmental performance other than proper ranking } \\
\text { using content analysis from indicators in the table above using } 0-3 \\
\text { assessment criteria. For brief disclosure categories given number } 1 \text {, } \\
\text { if disclosures are carried out in more detail in one paragraph, number } \\
2 \text { is given, while disclosures are carried out in detail. accompanied } \\
\text { by quantitative data given number } 3 \text {, but if not disclosed given } \\
\text { number } 0 \text {. In the case of measurement of Proper Rank given the } \\
\text { following rating: } \\
\text { a. No disclosure }=0 \\
\text { b. Black is given }=1 \\
\text { c. Blue is given }=2 \\
\text { d. Green is given }=3 \\
\text { e. Gold is given }=4\end{array}$ & \\
\hline$E R M$ & 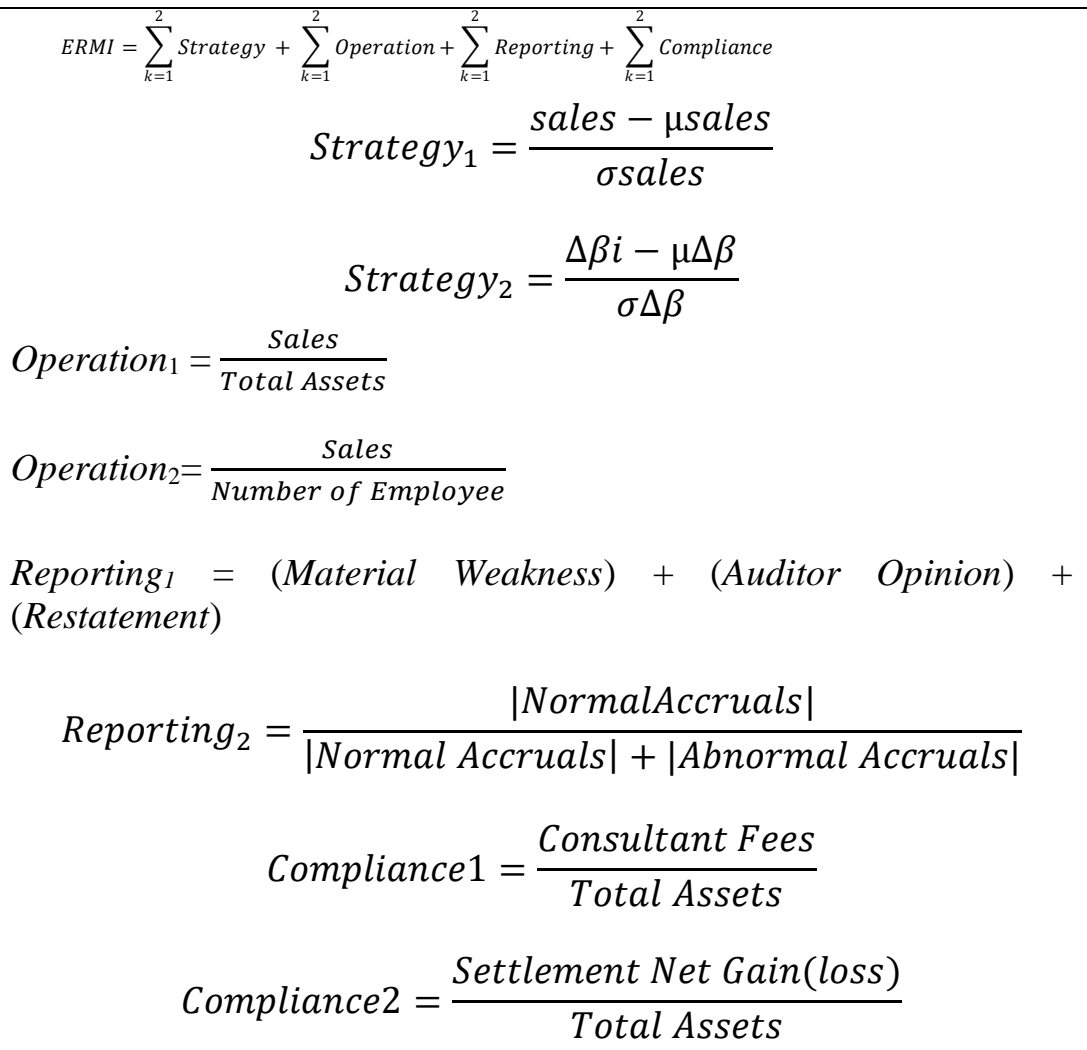 & $\begin{array}{l}\text { Gordon et al., } \\
2009\end{array}$ \\
\hline $\begin{array}{l}\text { Bussiness } \\
\text { Strategy }\end{array}$ & $\begin{array}{l}\text { The steps for calculating the strategy are as follows: } \\
\text { 1. Calculate four proxies in determining strategy: } \\
\text { a. MERS: marketing expense (selling, administration, dan } \\
\text { general expense) to sales Ratio. } \\
\text { b. COGSR: Cost of Goods Sold to Sales Ratio (Lin et al., } \\
\text { 2014). } \\
\text { c. CASGR: Compound Annual Sales Growth Rate (CASGR). } \\
\text { The calculation is as follows: } \\
\qquad \text { CASGR }=\left(\frac{\text { Ending Value }}{\text { Beginning Value }}\right)^{\left(\frac{1}{\# \text { of years }}\right)}-1 \\
\text { d. CIR: Capital Intensity Ratio: Net property, plant and } \\
\text { equipment to total assets. } \\
\text { 2. Combining scores from four proxies (Point 1) } \\
\text { 3. Calculate the combined score using quantil. To calculate the }\end{array}$ & $\begin{array}{l}\text { Anwar \& } \\
\text { Hasnu, } 2016\end{array}$ \\
\hline
\end{tabular}

2019 | International Journal of Financial, Accounting, and Management/ Vol 1 No 1, pp. 1-12 


\begin{tabular}{|c|c|c|}
\hline & $\begin{array}{l}\text { combined score, the highest quintile is given a score of } 4 \text { while } \\
\text { the observation in the lowest quintile is given a score of } 0 \text {. The } \\
\text { reverse rating is calculated for CIR. } \\
\text { 4. Scores are summed up over four steps in such a way that the } \\
\text { company can receive a maximum score of } 16 \text { and a minimum } \\
\text { score of } 0 \text {. Discrete "Strategy" scores range along the continuum } \\
\text { in values from } 0 \text { to } 16 \text { with Defender and prospector companies } \\
\text { closer to the end point and the remaining companies which are } \\
\text { the middle part of the continuum. } \\
\text { 5. Determination of the strategy of the sum of the combined } \\
\text { quintiles: Pure Defender }(0-3) \text {; DA-Like }(4-6) \text {; Pure Analyzer } \\
\text { (7-9); PA-Like (10-11); and Pure Prospectors (13-16). } \\
\text { 6. Giving a score for determining business strategy, as follows: } \\
\text { a. Pure Defender is given a number } 1 \\
\text { b. Defender Analyzer is given a number } 2 \\
\text { c. Pure Analyzer is given a number } 3 \\
\text { d. Prospector Analyzer is given a number } 4 \\
\text { e. Pure Prospector is given a number } 5\end{array}$ & \\
\hline $\begin{array}{l}\text { Foreign } \\
\text { Ownership }\end{array}$ & Foreign ownership $=\frac{\text { Foreign Ownership }}{\text { Number of shares issued }}$ & $\begin{array}{l}\text { Musfialdy and } \\
\text { Savitri, } 2015\end{array}$ \\
\hline Leverage & Total Debt / Total Equity & $\begin{array}{l}\text { Lestari \& } \\
\text { Juliarto, } 2017\end{array}$ \\
\hline
\end{tabular}

\section{Research result and discussion}

With sample of 44, the regression results indicate (models 1-3) that all significant regression models and all hypotheses except $\mathrm{H} 4$ are supported.

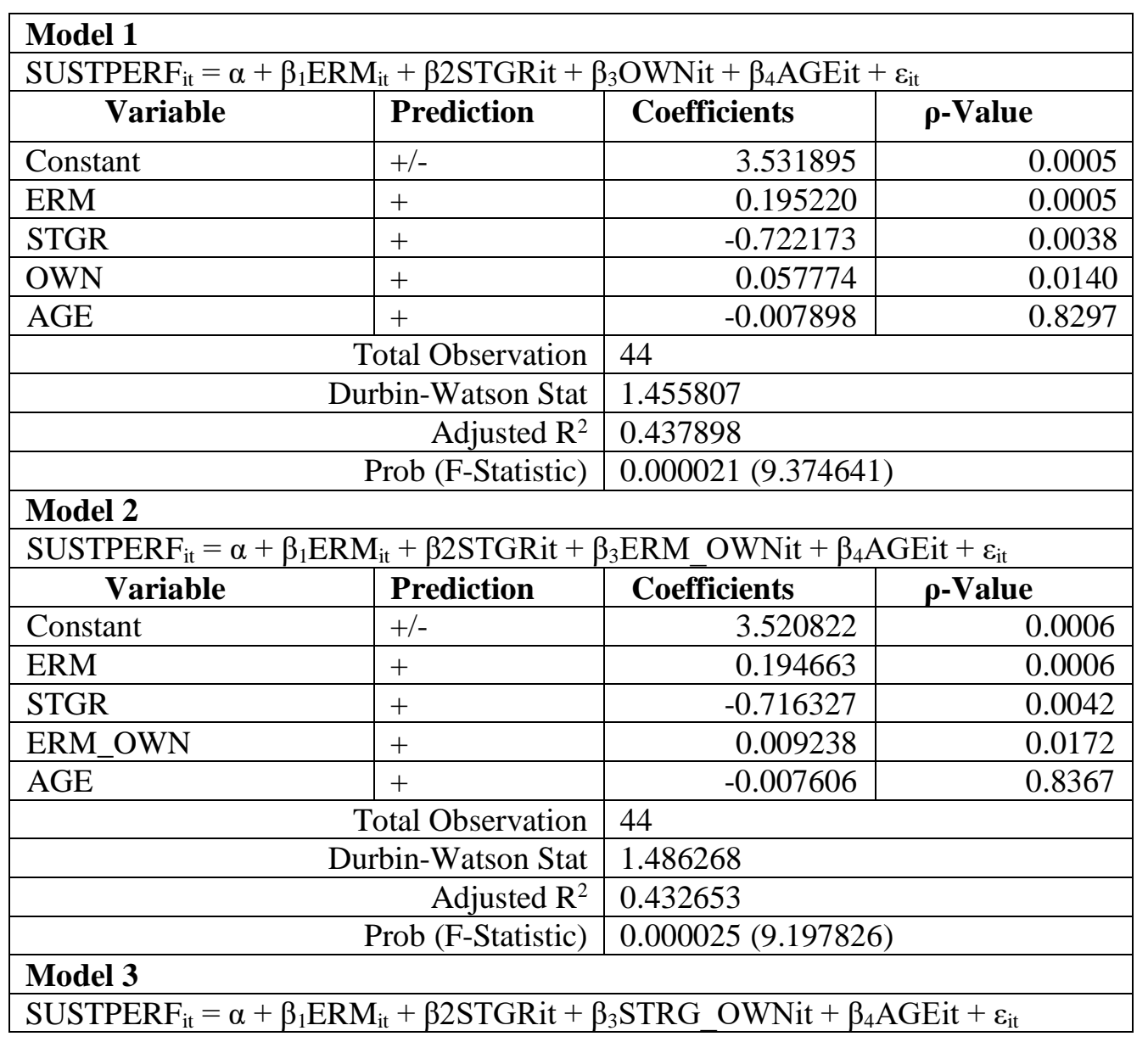




\begin{tabular}{|l|l|r|r|}
\hline \multicolumn{1}{|c|}{ Variable } & Prediction & \multicolumn{1}{c|}{ Coefficients } & \multicolumn{1}{c|}{$\boldsymbol{\rho}$-Value } \\
\hline Constant & $+/-$ & 3.575291 & 0.0004 \\
\hline ERM & + & 0.196020 & 0.0004 \\
\hline STRG & + & -0.750435 & 0.0025 \\
\hline STRG_OWN & + & 0.023128 & 0.0113 \\
\hline AGE & + & -0.006499 & 0.8587 \\
\hline \multicolumn{3}{r|}{ Total Observation } & 44 \\
\hline & Dudjusted R ${ }^{2}$ & 0.443406 \\
\hline & Prob (F-Statistic) & $0.000017(9.563911)$ \\
\hline
\end{tabular}

The table above, Model 1 shows that enterprise risk management, and foreign ownership shows $\rho$-value less than 0.05 and the regression coefficient is positive, so $\mathrm{H} 1$, and $\mathrm{H} 3$ are accepted, while $\mathrm{H} 2$ is rejected due to $\rho$-Value less than 0.05 but regression coefficient has a negative sign and $\mathrm{H} 4$ is rejected because $\rho$-Value is more than 0.05 . Adjusted R2 value shows $43.79 \%$ which means that enterprise risk management, business strategy, foreign ownership and company age have an influence of $43.79 \%$ on sustainability performance.

The first hypothesis which states that enterprise risk management has a positive and significant effect on sustainability performance is accepted. The result of this study indicates that enterprise risk management has a positive and significant effect on sustainability performance. This result is due to the increasingly good level of enterprise risk management that enables companies to be better able to filter out risks that can have a significant impact on the company as a whole.

Enterprise risk management in manufacturing companies in Indonesia is proven to be able to manage and monitor the risks and opportunities that exist from internal and external companies both social, environmental, and economic. With good risk management that has four objectives, namely strategy, operations, reporting and compliance, the company can improve sustainability performance. The result of this study is concurring to Florio and Leoni (2017) which states that enterprise risk management has a positive and significant effect on company performance both financial performance and market performance but Quon and Maingot (2012) which states that enterprise risk management has no effect on business performance. It has been mentioned in the previous section that as long as the researcher's knowledge does not yet exist, studies directly see the effect of enterprise risk management on sustainability performance.

The second hypothesis which states that business strategies have a positive and significant effect on sustainability performance is rejected. The result of this study indicates that business strategy has a negative and significant effect. Judging from the business strategy run by manufacturing companies in Indonesia, the strategy that is carried out mostly is a defender analyzer, pure analyzer and some other prospector analyzers. The company's business strategy in this study shows that the business strategy set by the company has not been running properly, that is, it can improve sustainability performance. It is possible that manufacturing companies in Indonesia have not succeeded in executing the strategies that have been compiled, this statement is reinforced by data from a study conducted in 2011-2012 on 175 companies in Indonesia, only 37.5 percent managed to execute the strategies that have been compiled, whereas The remaining 62.5 percent failed (Tempo.co, 2015). The results of this study is according to Ajagbe et al. (2016) which states that business strategies affect company performance but it is not concurring to Martinez \& Poole (2004) who have failed to prove the influence of business strategies on company performance. Direct research that examines the effect of business strategies on sustainability performance has not been found throughout the knowledge of researcher.

The third hypothesis which states that foreign ownership has a positive and significant effect on sustainability performance is accepted. The result of this study indicates that foreign ownership has a positive and significant effect on sustainability performance. Foreign ownership is trusted in making decisions more concerned with social and environmental issues in addition to the economy. Foreign ownership in manufacturing companies in Indonesia in this study does not exceed $50 \%$ so foreign ownership has a significant influence on the company. Although some cases relating to environmental issues involve foreign parties, from this research it can be

2019 | International Journal of Financial, Accounting, and Management/ Vol 1 No 1, pp. 1-12 
proven that foreign parties pay more attention to environmental and social issues in companies at a ownership level of less than 50\%. The results of this study are in line with Moustafa (2012), Dalilawati (2013) and Darus et al. (2013) which states that foreign ownership has a positive and significant effect on CSR disclosure but Winarti (2014), Hartikayanti (2016), and Kim et al. (2018) failed to prove the influence of foreign ownership on CSR activities.

The fourth hypothesis which states that firm age has a positive and significant effect on sustainability performance is failure to be accepted. This result indicates that the age of the company does not affect sustainability performance. Companies that have long been in the same industry do not necessarily make the company pay attention to social and environmental issues. This is probably because environmental and social issues have not been able to increase their profitability economically. The result of this study agrees to Badulescu et al. (2018) which states that the age of the company does not affect CSR activities which can be concluded not to affect sustainability performance but not in line with Wang et al. (2018) which succeeded in proving that the age of the company had a positive and significant effect on Sustainable Performance Improvement. The calculation results in the table above (model 2) can be seen that foreign ownership strengthens the impact of enterprise risk management. P-Value 0.0172 is smaller than 0.05 and regression coefficient is positive. Thus H5 which states that foreign ownership strengthens the influence of enterprise risk management on sustainability performance is accepted.

The fifth hypothesis which states that foreign ownership strengthens the influence of enterprise risk management on sustainability performance is accepted. The result of this study indicates that foreign ownership is proven to have a better system that can be applied in monitoring and managing risk. Foreign ownership also allows companies to know more about foreign markets so that the level of risk is lower. Better risk management in environmental, social and economic dimensions will improve sustainability performance. The calculation results in the table above (model 3) can be seen that foreign ownership strengthens the impact of Business Strategy. P- Value 0.0113 is smaller than 0.05 and regression coefficient is positive.

Thus H6 which states that foreign ownership strengthens the influence of Business strategy on sustainability performance is accepted. The sixth hypothesis which states that foreign ownership strengthens the influence of business strategies on sustainability performance is accepted. The result of this study indicates that with foreign ownership, the business strategy set by manufacturing companies in Indonesia can run so that the company's goals are achieved. Foreign parties are seen as having better capabilities in determining and implementing company strategies so that they can improve sustainability performance.

\section{Conclusion}

The purpose of this study is to determine the effect of enterprise risk management, business strategy, foreign ownership and company age on sustainability performance. In this study, it is proven that enterprise risk management, foreign ownership has a positive and significant effect on sustainability performance. The age of the company was not successfully proven its influence on sustainability performance. The business strategy that was established but it turned out that it could not be fully implemented by companies in Indonesia, it was evident that in this study business strategy had a significant negative effect on sustainability performance.

This study also aims to determine the impact of foreign ownership in strengthening the influence of enterprise risk management and business strategies on sustainability performance. This research can prove that foreign ownership can strengthen the influence of enterprise risk management and business strategies on sustainability performance. Foreign ownership can significantly influence the decisions and policies taken by the company so that it can improve sustainability performance.

This study uses a sample of manufacturing companies consisting of 11 companies with the period 2014-2017. With this sample it can be said that this research cannot represent all manufacturing companies in Indonesia. Nevertheless, this study has been able to prove a considerable influence seen from the adjusted $\mathrm{R}^{2}$ value. 
For further research related to sustainability performance, it can be done on more samples. Other variables can also be used such as company size, leverage, and intellectual capital. Research data for further research can be equipped with primary data in addition to secondary data.

\section{References}

Aderi, B \& Elisabet H. (2018). Menggugat perusak asing demi restorasi lingkungan. https://www.validnews.id/Menggugat-Perusak-Asing-Demi-Restorasi-Lingkungan-dkj.

Aditya, A \& Chandra G.A. (2018). RI buka 100\% kepemilikan saham asing di 54 sektor usaha. https://www.cnbcindonesia.com/market/20181116105546-17-42473/ri-buka-100kepemilikan-saham-asing-di-54-sektor-usaha

Anwar, J \& SAF Hasnu. (2016). Business strategy and firm performance: a multi-industry analysis. Journal of Strategy and Management, Vol. 9 Iss 3. http://dx.doi.org/10.1108/JSMA-09-2015-0071

Badulescu, A, Daniel B, Tomina S, \& Roxana H. (2018). The relationship between firm size and age, and its social responsibility actions-focus on a developing country (romania). doi:10.3390/su10030805

Candra A.A. (2016).60\% Kepemilikan saham di BEI dikuasai investor asing. https://finance.detik.com/bursa-dan-valas/d-3321821/60-kepemilikan-saham-di-beidikuasai-investor-asing

Chapple, W., \& Moon, J. (2005). Corporate social responsibility (CSR) in asia a seven-country study of CSR website reporting. Business \& society, 44(4), 415-441.

Committee of Sponsoring Organizations of the Treadway Commission COSO. (2004). Enterprise risk management-integrated framework (COSO - Enterprise Risk Management Report).http://www.coso.org/documents/coso_enterprise_risk_management_executives ummary.pdf

Cooper, L.G \& Masao N. (1988). Market-share analysis evaluating competitive marketing effectiveness. https://www.researchgate.net/publication/259583948

Dahwilani, Dani M. (2017). Inovasi samsung desain produk ramah lingkungan. https://autotekno.sindonews.com/read/1215681/124/inovasi-samsung-desain- produkramah-lingkungan-1498055353

Dalilawati, Z \&Suria Z. (2013). Corporate social responsibility reporting in Malaysia: a research note. Journal of Accounting Perspectives, Vol. 6, pp. 21-36

Dam, L., \& Scholtens, B. (2012). Does ownership type matter for corporate social responsibility? Corporate Governance: An International Review, 20(3), 233-252.

Gordon, L.A, Martin P.L, \&ChihY.T. (2009). Enterprise risk management and firm performance: A contingency perspective. J. Account. Public Policy 28: 301-327

Hartikayanti, Heni N \&Ifan W.S. (2018). The effect of stock ownership toward the Corporate Social Responsibility (CSR) disclosure. International Conference of Organizational Innovation, KNE Social Sciences, Pp 1314-1324. Doi: 10.18502/kss.v3i10.3472.

Hartikayanti, Heni N,M., Ryan T \& ER Budhi S. (2016). Effect of corporate characteristics on environmental disclosure, International Journal of Applied Business and Economic

2019 | International Journal of Financial, Accounting, and Management/ Vol 1 No 1, pp. 1-12 
Hintošová, A.B \&Zuzana K. (2016). The effect of the degree of foreign ownership on firms' performance. Review Of Economic Perspectives - Národohospodářský Obzor Vol. 16, Issue 1, 2016, Pp. 29-43, Doi: 10.1515/Revecp-2016-0003

Jensen, M. (2001). Value maximisation, stakeholder theory, and the corporate objective function. European Financial Management, 7(3), 297-317. doi:10.1111/1468- 036x.00158

Jordão, R,Vinícius D \& Vander R. A. (2017). Performance measurement, intellectual capital and financial sustainability. Journal of Intellectual Capital, Vol. 18 Issue: 3, pp.643-666, https://doi.org/10.1108/JIC-11-2016-0115

Kim, W.S, Kunsu P, Sang H.L. (2018). Corporate social responsibility, ownership structure, and firm value: evidence from Korea. doi:10.3390/su10072497 www.mdpi.com/journal/sustainability

Kurnia, T. (2018). Indeks inovasi global: Indonesia naik ke peringkat 85. https://www.liputan6.com/bisnis/read/3586722/indeks-inovasi-global-indonesianaik-ke-peringkat-85

Lestari, N.P \&Agung J. (2017). Pengaruh dimensi struktur kepemilikan terhadap kinerja perusahaan manufaktur. Diponegoro Journal of Accounting Volume 6, Nomor 3, Tahun 2017, Halaman 1-10. http://Ejournal-S1.Undip.Ac.Id/Index.Php/Accounting

Lewis, I. (2008). The quantum skills model in management: a new paradigm to enhance effective leadership. Leadership and Organizational Development Journal, 22(6): 264-273.

Malik, H.A, Syed M.A, \& Jan S.K. (2017). Impact of ownership structure on corporate social responsibility: evidence from Pakistan. International Journal of Scientific \& Engineering Research, Volume 8, Issue 1, January-2017. Pp 1938 - 1952.

Marwa, N.,\& Meshach A. (2015). Financial sustainability of Tanzanian saving and credit cooperatives. International Journal of Social Economics, Vol. 42 Iss 10: 870 - 887

Melatic, Matjaz et al. (2015). Do corporate sustainability practices enhance organizational economic performance?.International Journal of Quality and Service Sciences. Vol. 7 No.2/3: 184-200.

Miles R.E.- C. C Snow Meyer A.D., \& Cohleman H.C. (1978). Organizational strategy, structure, and process. Academy of Management Review, No. 3: 546-562

Musfialdy, \&Enni S. (2015). The effect of environmental performance, foreign ownership and leverage to disclosure of corporate social responsibility (study on manufacturing companies in Indonesia stock exchange). Global Journal of Business and Social Science Review, Vol. 4(1), October-December 2015. Pp 34-39

Oltra, M.J. \& M. L Flor. (2010). The moderating effect of business strategy on the relationship between operations strategy and firms results. International Journal of operations \& production management, Vol.30 No.6: 612-638

Osunsan,O.K., Jadwiga N, Eric M, Samuel P, Ally R.K, John B.B. (2015). Firm age and performance in Kampala, Uganda: a selection of small business enterprises. International Journal of Academic Research in Business and Social Sciences, Vol. 5, No. 4. Pp 412-422 
Peilouw, C. T. (2017). Pengaruh struktur kepemilikan terhadap kebijakan hutang pada perusahaan yang terdaftar di bursa efek Indonesia. Jurnal Akuntansi dan Perpajakan, Vol. 3, No. 1, Tahun 2017 1, Pp1-13

Pervan, M, Ivica P \&Marijana C. (2017). The influence of age on Firm Performance: Evidence from The Croatian Food Industry. Journal of Eastern Europe Research in Business and Economics. http://www.ibimaplublishing .com/journals/JEERBE/jeerbe.html.

Rao, P, \& Diane H. (2005). Do green supply chains lead to competitiveness and economic performance?. International Journal of Operations \& Production Management, Vol. 25 Issue: 9, Pp.898-916, https://doi.org/10.1108/01443570510613956

Saltaji, \&Issam M. (2013). Corporate governance relation with corporate sustainability. Internal Auditing dan Risk Management, 8(2): 137-147.

Sar, A.K. (2014). The dynamics of corporate governance and sustainability: a study of the Indian electricity generation industry. International Journal of Business Ethics in Developing Economies. Volume 3 Issue 2 December 2014: 15-21

Taiwo, JN, Achugamonu BU, Okoye O, \&Agwu, M.E. (2017). Foreign direct Investment: catalyst for sustainable economic development in Nigeria. Saudi Journal of Business and Management Studies. DOI: 10.21276/sjbms.2017.2.2.2

Tempo.co. (2015). Mengeksekusi strategi, menciptakan bisnis berkelanjutan. https://bisnis.tempo.co/read/727069/mengeksekusi-strategimenciptakan-bisnisberkelanjutan/full\&view $=$ ok

Trencansky, D \& Dimitrios T. (2014).The effects of company's age, size and type of industry on the level of CSR: The development of a new scale for measurement of the level of CSR. Master Thesis. Umeå School of Business and Economics

Wang, J., Yuchen Z, \& Mark G. (2018). Moderating the role of firm size in sustainable performance improvement through sustainable supply chain management. doi:10.3390/su10051654

Winarti (2013). Pengaruh kepemilikan pemerintah (BUMN) dan kepemilikan asing terhadap luas pengungkapan tanggung jawab sosial perusahaan pada laporan tahunan perusahaan. Jurnal TEKUN Volume IV, No.02, pp. 305-316

Yuan, Y, Louise Y. L, Gaoliang T \&Yangxin Y. (2018). Business strategy and corporate social responsibility. Journal of Business Ethics. https://doi.org/10.1007/s10551-018-3952-9

Yulistara, A. (2018). 60\% Orang Indonesia pilih beli produk asing ketimbang lokal. https://www.cnbcindonesia.com/lifestyle/20180326194751-33-8635/60orang- indonesia-pilih-beli-produk-asing-ketimbang-lokal 